\title{
DE WAARDE ALS MAATSTAF VOOR DE GRONDBELASTING.
}

I.

Wanneer in onderstanande beschouwingen de wenschelijkheid eener nadere regeling der grondbelasting wordt bepleit, dan moet hier niet een betoog verwacht worden over de economische werking dezer belasting, maar over de praktische toepassing.

Waar de eerste op uitvoerige wijze door de beste staathuishoudkundigeu is uiteengezet, zij het mij vergund, ter aanduidiug van de richting, waarin die regeling zou moeten plaats hebben, naar hunne uitspraken te verwijzen.

"Men beweert wel eens, dat de grondbelasting van lauderijen, "om volkomen geamortiseerd te worden, een fixum moet zijn. "Dit is onjuist. Volmaakt kau de amortisatie hier eerst wezen, "wanneer de grondbelasting in een onvernuderlijk deel van de "jaarlijksche zuivere opbrengst bestaat. Het fixum maakt haar "onvolkomen." ( $\mathrm{M}^{\mathrm{r}}$ N. G. Pierson, Leerboek der Staathuishoudkunde, tweede deel, bl. 402.)

"Uit het aangevoerde is echter wel de conclusie te trekken "dat niet nar fixeering van het bedrag maar nanr eeu vast "percentage der grondbelasting gestreefd moet worden." ( $\mathrm{M}^{\mathrm{r}}$ M. F. W. Treub, Vragen des Tijds, 1890 II, bl. 34.)

"Als voorwaarde voor afwenteling door kapitaal-vermindering "moet men weten, wat men zal kapitaliseeren. Hoe vaster de "Inatste hoe gemakkelijker de waardeering eu amortisatie." ( $\mathrm{M}^{\mathrm{r}}$ P. W. A. Cort van der Linden. Vragen des Tijds, 1890 II bl. 118.)

Tot toelichting wordt verder betoogd, hoe wisselvallig de waarde van den grond is. Periodieke schattingen bij vastheid van percentage zullen dus aan dit bezwaar tegemoet komen.

"De werking der afwenteling wordt onmiddelijk belemmerd "en gestuit, wanneer de opbrengst ophoudt". (Mr P. W. A. Cort van der Linden. Vragen des Tijds 1890, II bl. 123.) Hieruit volgt duidelijk de gebiedende eisch eener periodieke herschatting.

Econ. 1904. 
Zelfs $M^{r}$ S. Vissering, die overigens de meening is toegedan, dat de grondbelasting is een vaste grondrente, die onveranderlijk behoort te zijn, zegt in stelling 841: "Alleen dan, wanneer de "prijs van den grond door algemeen werkende oorzaken aan"merkelijk gewijzigd wordt, kan er reden zijn voor eene ver"andering in het bedrag der grondbelasting."

Terwijl bij elke perequatie, op onwillekeurige en niet vooruit verwachte tijden ondernomen, dikwijls niet degeen wordt gebaat, die door achteruitgang in de pachtwaarde de waarde van zijn goed zag verminderen, als hij op dat oogenblik geen eigenaar meer is, legt daarentegen eene verhooging van grondbelasting, tengevolge dier prequatie, een zwaren last op de schouders van hem, die bij ankoop een hoogeren prijs heeft besteed wegens de hoogere waarde. Om dit nadeel te verzachten bestaat slechts een middel, n.l. verlaging van het totaal der belasting. Zoo heeft dan ook de perequatie-wet van 1892 aan het Rijk f 960.000 gekost, terwijl toch de pachtwarde sedert de invoering van het kadaster enorm was gestegen.

Ook na de herziening 'van de belastbare opbrengst der gebouwde eigendommen krachtens de wet van 1873 heeft het Rijk van de enorme stijging der huurprijzen sedert de invoering van het kadaster geen voordeel getrokken, maar is toen het inderdaad zeer hooge percentage van gemiddeld voor het geheele Rijk 12,29 pCt. teruggebracht op 5.2039 pCt. (Door de vroegere provinciale quota's was de verhouding tusschen de belasting en de belastbare opbrengst in elke provincie niet gelijk, maar varieerde tusschen 10.57 pCt. voor Limburg en 12.84 pCt. voor Friesland, zie de Statistiek van het Koninkrijk der Nederlanden, uitkomsten der herziening van de belastbare opbrengst der gebouwde eigendommen, 's Gravenhage 1876.).

Bij de thans annhaugige herziening dierzelfde opbrengst, zullen de uitkomsten weder niet onbelangrijk hooger zijn dan bij de hiervoor genoemde. Of dit ook tot hoogere opbrengst voor het Rijk zal leiden is nog de vraag; zeer waarschijulijk zal echter het percentage-cijfer wederom eene vermindering ondergaan. Indien evenwel die uitkomsten eens ongunstiger geweest waren, zou dan het percentage-cijfer verhoogd moeten worden? Dit ware inderdand eene averechtsche belasting, hooger belasting bij minder opbrengst. 
II.

Mag men llus annemen, dat het voor eene goede regeling der grondbelasting eisch is, dat deze met de verhooging of verlaging der huurwaarde op en neer gaat, eene andere vraag is, of, in plaats van die huurwaarde, de koopwaarde tot basis van aanslag kan worden genomen. Is, zooals in normale gevallen, alleen de huurwaarde der gebouwen of de pachtwanrde der lauderijen, de maatstaf voor de werkelijke waarde, dan is de uitkomst natuurlijk hetzelfde, doch blijft het nadeel bestaan; dat bij verandering van den rentestand de waarde van het vast goed verandert en dus ook de belasting zou moeten veranderen, zonder dat de opbrengst eenige wijziging onderging, en toch is die opbrengst de bron, waaruit moet worden betaald. Doch de vraag komt mij gewettigd voor of men bij aankoop van gronden niet meer met een gemiddelden rentevoet rekening zal houden, darr de wisseling van eigenaar niet zoo dikwijls roorkomt als bijv. bij effecten en men zich dus onwillekeurig bij aankoop het bezit van langeren duur voorstelt. Ook zou aan dit bezwaar eenigszins tegemoet te komen zijn door, bij de berekening der belasting dien rentevoet niet te hoog te nemen; men moet zich werkelijk ook niet voorstellen, dat de grondeigenaar zooveel rente van zijn kapitaal maakt, vooral niet bij de ongebouwde eigendommen.

Toch is het bezwaar niet weg te cijferen en rest dus de vraag of de voordeelen, die voortvloeien uit een anderen grondslag dan de huur- of pachtwaarde, inderdaad groot genoeg zijn, dat zij de schaal ten voordeele van dien nieuwen grondslag doen overhellev.

III.

Die vraag kan teruggebracht worden tot deze: behooren de omstandigheden die wel grooten invloed hebben op den koopprijs maar niet of weinig op den huur- of pachtprijs, invloed te hebben op de hoegrootheid der belasting? Eene benntwoording, anders dan toestemmend, schijnt mij onmogelijk.

Vergelijkt men twee gebouwen, die beiden dezelfde ruimte en gemakken aanbieden, terwijl het eene bestemd om te verhuren, zoo eenvoudig mogelijk is afgewerkt en het andere, dat de eigenarr voor zich zelf heeft laten zetten, uitstekend is gebouwd en daaraan geene kosten zijn bespard, dan zal toch het 
laatste weinig meer in huur doen, ja men kan zich voorstellen, clat het tweede gebouw iets minder ruim wordt, zoodat de huurprijs met het eerste gelijk komt, terwij] toch de innerlijke waarde enkele duizende guldens meer kan bedragen, moeten dan toch deze gebouwen evenveel in de grondbelasting bijdragen?

In Ellecom, aan den Rijksstraatweg tusschen Dieren en de Steeg zijn op twee naast elkander gelegen perceelen, tegelijkertijd twee huizen gebouwd. Het huis op perceel I, groot $1670 \mathrm{M}^{2}$. is kleiner en vooral de bovenverdieping heeft veel minder ruimte dan dat op perceel II, groot $1630 \mathrm{M}^{2}$., waarop zich bovendien nog eene flinke steenen schuur bevindt. Perceel $I$ is echter gebouwd voor rekening van een rentenier en veel beter gebouwd ell afgewerkt dan perceel II, dat voor pension dient.

In overeenstemming met deze toelichtingen is perceel I geschat op eene belastbare opbrengst gebouwd van f 475 . - eu ongebouwd van $f 20.04$ en perceel II respectievelijk op $f 600$.en $f 19.56$, terwijl het huis op perceel $I$ heeft gekost van bouwen f 11000 . - en dat op perceel II $f$ 9000.-

Een ander voorbeeld: twee huizen brengen ieder f 1000.huur op, maar het eene kost jaarlijks ann onderhoud f 100.- , het andere f 300.- Moet toch de belasting voor beiden gelijk zijn, zooals de wet thans voorschrijft? Wel kan aan dit bezwaar worden tegemoet gekomen, door ook voor de gebouwde eigendommen de zuivere huurwaarde als basis aan te nemen, zooals de Minister Pierson dit in zijn wetsontwerp had voorgesteld (iugediend bij Kon. Boodschap van 29 Juni 1893, zitting 1892-1893, No. 193), door schatting n.l. van de onzuivere huurwaarde en van de onderhoudskosten, maar de schatting van deze laatste is uiet van groote bezwaren outbloot en door aauneming der waarde tot basis komt men op eenvoudiger, voor elk perceel zuiverder en voor den belastingschuldige gemakkelijker te controleeren wijze tot dezelfde uitkomsten.

Bij de wet van $10 \mathrm{Juli} 1902$ is aan de stad Parijs toegestaan ecne belasting van hoogstens 1 per mille te heffen vau de kapitaalswaarde der gebouwde en ongebouwde eigendommen. (Zie Bulletin de Statistique et de Législation comparée, Juillet 1902 , bl. 5). Interessante mededeelingen omtrent de voorbereidiug en uitvoering dezer wet zijn opgenomen in het Bulletin van Mart 1903, bl. 362 en volg. Omtrent hetgeen wat moet 
worden verstann onder ouroerende wande van een eigendom wordt gezegd:

"Cette valeur ne pouvait representer le prix du terrain et "des constructions, car les immeubles sont soumis à la loi de "l'offre et de la demande et leur valeur vónale n'a parfois "aucuu rapport avec leur prix de revient. Snns compter que ce "prix de revient devrait être atténué à raison de la dépréciation "que subit un bâtiment au fur et à mesure qu'on s'éloigne de "l'époque de sa construction et que le quantum de cette dépré"ciation serait très-difficile à fixer.

"La valeur immobiliè re ne pouvait pas davantage se con"fondre, d'une façon absolue, "avec la valeur vénale résultant "d'un acte authentique.

"Dans beaucoup cle cas, il est vrai, cet élément du prix de "vente est le critérium le plus sûr et le moins discutable. On ue "saurait, toutefois, l'accepter sans réserve : on sait bien, en effet, "que certaines circonstances particulières que accompagnent une "vente, rendent, par fois, les actes authentiques peu probants. "En fait, nous avons eu pour objectif de fixer une valeur "en capital normale et proportiouelle, en appréciant les "divers éléments qui pouvaient influer sur elle et nous avons "eu recours, pour déterminer cette valeur, aux deux procédés "qui nous ont semblé présenter le plus de garantie et de cer"titude: l'évaluation par le fonds et l'évaluation par le revenu."

Fene beschouwing, in hoeverre de koopacten voor deskundige mannen, met gezond rerstand bedeeld en die rich niet bepaleu lot het opnemen van de daarin voorkomende cijfer's, genoegzame gegevens bezitten om de normale en evenredige koopprijzen te viuden, valt buiten het kader van dit opstel, doch gewezen mag hier worden op de vrijheid vau beweging en van de keuze der middelen, wanrover de administratie mocht beschikken om tot haar doel te geraken.

Slechts wil ik nog aanhalen, als toepasselijk op-het begiusel der wet, het zesde lid van art. 1 : "Il ne sera accordé ancun "dégrèvcment pour cause de vacance de maison ou de chômage "d'usiue."

IV.

Ook voor het ongebouwd zullen plaatselijk bekende personen, 
die af en toe met het kadaster in aanraking komen, dikwijls gestuit ziju op schattingen, die hun niet juist voorkomen, alleen omdat de werkelijke pachtwaarde als basis was genomen. Zoo ziet men thans dikwijls naast elkander gelegen perceelen van gelijke $k$ waliteit verschillend geschat, omdat de een zijn land goed onderhouden heeft en de ander er niets aan doet. $\mathrm{Nu}$ wordt bij belasting naar de pachtwaarde de eigenaar vau het eerste stuk veel zwaarder belast dan die van het tweede stuk en deze onbillijkheid kan slechts vermeden worden door de koopwaarde tot basis te nemen daar bij verkoop het uiet goed onderhouden stuk, welks productief vermogen men heeft laten sluimeren, weinig minder zal opbrengen dan het audere. Dit productief vermogeu rindt toch in de koopwaarde beter afspiegeling dan in de pachtwaarde. Dikwijls kan eene eenvoudige cultuursverandering, met weinig kosten tot stand te brengen, al verschil in pachtwaarde veroorzaken, zonder op den koopprijs merkbaren invloed uit te oefenen en waar de schattingen nu al meer dan 15 jaar oud zijn is het verband der geschatte huurwaarde dikwijls verbroken en komt men soms voor vreemde resultaten te staan, die, bij aanneming van den koopprijs tot groudslag, zouden zijn vermeden. Schattingen als neveustaande in de gemeente Slijk-Ewijk zouden niet voorkomen.

De juistheid dezer bewering met cijfers te staven is zeer lastig. Om te bewijzen dat de koopprijzen ongeveer gelijk ziju, zouden minstens twee perceelen moeten zijn verkocht op viet te ver vau elkander gelegen tijdstippen en om an te toonen dat de schattingen juist zijn, zouden diezelfde perceelen moeten zijn verhuurd. Deze samenloop van omstandigheden is moeilijk te treffen, doch ik geloof mij op het oordeel van deskuudigen te mogen beroepen om de juistheid te bevestigen.

Van enkele perceelen, gelegen te Oldebroek aan den straatweg van Zwolle unar Elburg, is mij als verkoopwaarde per hectare, door aldaar wonende landbouwers, opgegeven pl. m. f 1200.voor een perceel geschat op f $35 .-$ per hectare en pl.m. f 1000 . - voor perceelen, geschat op $f$ 20.-.

Van het tegenovergestelde geval, gelijkheid van opbrengst, bij ongelijkheid der waarde, kan ik echter een sterk sprekend voorbeeld annhalen. 


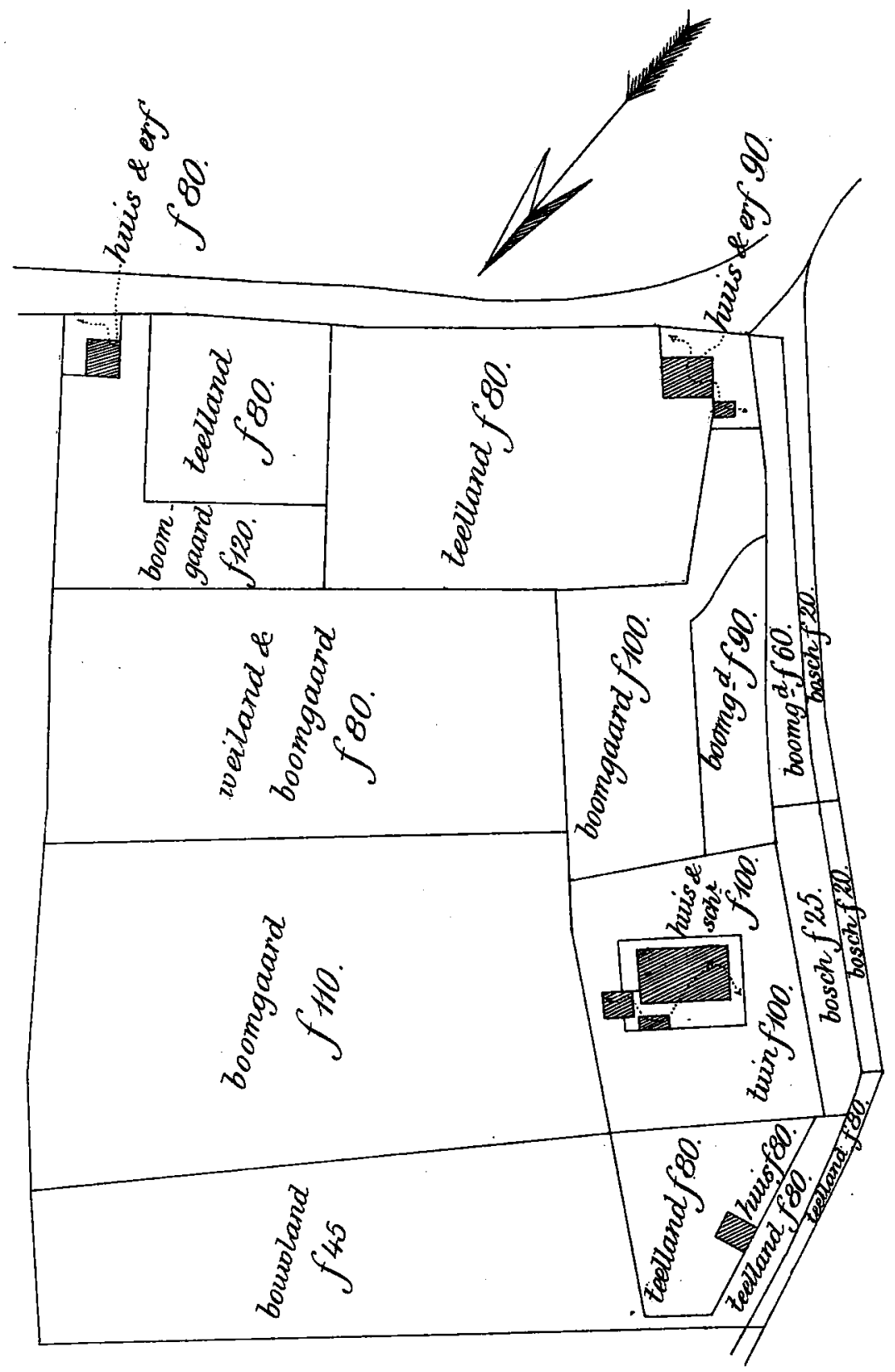


In Olșt zijn twee perceelen, G. 1334 eṇ 1337 samen groot 1.81.60 hectaren in 190: verkocht. Zij zijn gelegen ann den linkel IJseloever (zooals men weet is een deel der gemeente Olst over den IJsel gelegen) buitendijks, juist, tegen de scheiding der gemęente Epe en Oene. Die perceelen, gedeeltelijk uit bouwland en geileeltelijk uit grasland bestaande, hebben opgebracht $\mathrm{f}$ 2825.terwijl het onraad, ten laste van den kooper f 258. - bedroeg, zoodat deze stukken hem hebben gekost $\mathrm{f} 3083$.-

Het bouwland is verhuurd voor $\mathrm{f} 90$ 's jaars het grasland heeft opgebracht in $1902 \mathrm{f} 53 .-$ en in $1903 \mathrm{f} 55 .-$, gemiddeld $f 54$ terwijl de onkosten voor afrikking, kunstmest, enz. kunnen wor: den gesteld op samen f 10.-, blijft dus f 134. - zuivere opbreugst.

Dezelfde eigenaar had in 1893 een perceel weinig waardig hooiland aangekocht in de gemeente Epe, kadastraal bekend onder de sectie $K n^{\text {os }} .995$ en 560 , samen groot 1.74 .05 hectaren, voor deul prijs van $f 328$. - , het onraad was f 47.- zoodat dit stuk hem heeft gekost f 375.- Dit perceel was vroeger verhuurd voor f 15.-

Dit stuk heeft hij met slakkenmeel en kaïniet bezaaid en wel voor den oogst van 190030 zakken, van 190135 zak, van 1902, 40 zak en van 190336 zak, samell 141 zak.

Be opbrengst vau het gras gewas was in 1900. . f 203.-

$$
\begin{array}{r}
\text { in } 1901 \ldots-226 .- \\
\text { in } 1902 . \ldots-228 .- \\
\text { in } 1903 . \ldots-140 .- \\
\text { samell. . . f } 797 .-
\end{array}
$$

De zakken slakkeumeel en kaïuiet hebben hem gekost gemiddeld $f 2.25$ per znk, terwijl er f 0.20 per zak werkloon er bearbeiding op het land bijkwam, dus samen per zak f 2.45 , makende voor de 141 zak. . . . . . . . . . . . . f 345.45 of gemiddeld per jaar f 113.- - zuivere opbrengst.

blijft. . . f 4151.55

Thans wordt de waarde door den eigenaar getaxeerd op $\mathrm{f} 800$.... $O p$ het oogenblik heeft het eerste stuk land eene belastbare opbrengst van f 121.96 het tweede van f 14.19.

$\mathrm{Nu}$ is het toch kwalijk vol te houden, dat bij eene herschatting die beide stukken, als thans gemiddeld ongeveer dezelfde zuivere pacht hebbende opgebracht ongeveer gelijk geschat zouden moeten worles. 
V.

Heb ik hiervoor getracht aan te toonen, dat de koopwanrde als meer het productief vermogen weergevende, beter maatstaf angeeft dan de pachtwaarde, nog duidelijker komt dit uit bij de bouwterreinen, die eene bijzondere en hooge waarde ontleenen aan omstandigheden, onafhankelijk van hun productief vermogen of van hunne pachtwarde. De wet van 25 April 1879, Stbl. $\mathrm{n}^{\mathrm{n}}$. 89, waarmaar de laatste schattingen der ongebouwde eigendommen ziju geschied, bepaalde in het voorl. lid van art. 2: "Voor een open plaats en voor een erf, tuin of park, waarop gebouwen staan of waarbij gebouwen behooren, welke in de bebouwde kom eener gemeente gelegen zijn, wordt de hoogste pacht- of huurwanrde aangenomen, welke in die gemeente voor andere eigendommen is bepaald. $\mathrm{Nu}$ is in Amsterdam het hoogste bedrag vall de schaal van schatting f 450 .- , zoodat op grond daarvan zou mogeu worden aangenomen, dat zelfs bij de meest intensieve cultuur, zooals bij de moestuinen van Ansterdam in «wang is, de pacht tot geen hooger cijfer dan van 5 cent per vierkanten meter kan worden opgevoerd. De huurwaarde van een tuin bij een hnis aan de Heerengracht hiermede gelijk stellende komt men voor een tuin $500 \mathrm{M}^{2}$ tot eeue huurwaarde van $\mathrm{f} 25$. - . Dat de tuin naar dien martstaf te hoog belast is, zal wel niemand beweren. Bij belasting naar de verkoopwarde zou die tuin niet gelijk aan, maar vrij wat hooger zijn belast dan de grondeu in de slatuintjes.

Voor zooverre de bouwterreinen reeds bebouwd zijn, treedt de belnsting op de gebouwde eigendommen op om de groudeı naar hunne werkelijke huurwaarde aan te slaan.

De wetgever heeft bij de thans in behandeling zijude herziening van de belastbare opbrengst der gebouwde eigendommen aan dit begrip wettelijke sanctie gegeven door in art. 7 der wet van 2 Mei 1897, Stbl. No. 124, voor te schrijven, dat de belastbare opbrengst der ongebouwde eigendommen door de gebouwde eigendommen ingenomen of bij de berekening in aanmerking genomeu, van de vastgestelde belastbare opbrengst der gebouwde eigendommen moet worden afgetrokken.

Daargelaten, dat dit beginsel op juister, eenvoudiger en voor den belastingschuldige beter te controleeren wijze in toepassing had kunnen komell, door de schatting van het ongebouwd te 
elimineeren, zoolang de.huurwaarde danrvoor in de schatting van het gebouwd is uitgedrukt, verschilt ook de belasting op de gebouwde eigendommen zoozeer in ard en werking van de eigenlijke grondbelästing (die op de ongebouwde eigendommen) dat het middel niet afdoende genoemd mag worden en hiermede kom ik van zelf op een ander voordeel van het door mij aangeprezen stelsel, n.l.:

\section{VI.}

De mogelijkheid van de splitsing der belasting op de gebouwde eigendommen in eene belasting voor den grond en eene belasting voor het gebouw, dat er op staat.

De huurprijs, thans basis voor die belasting, bestaat feitelijk uit twee deelen, n.l. een huur voor het gebouw en een huur voor den grond, terwijl de grondbelasting op elk bestanddeel eene verschillende werking heeft (vergelijk het Leerboek der Staathuishoudkunde van Mr. N. G. Pierson, $1^{\text {e }}$ deel, bl. 136 en vlg. en bl. 141 en volg.) Die grondhuur vertoont in oorsprong en wezen veel overeenkounst met de grondrente of pachtwarde volgens de theorie van Ricardo, de wenschelijkheid om de belasting op de grondhuur tot de ongebouwde tering te brengen, mag dus bijna een axioma heeten.

Ook het tegenovergestelde geval, splitsing iler grondbelasting voor de boerderijen in die voor den grond en die voor de gebouwen, die er bij in gebruik zijn, zou eindelijk eens eene oplossing kunnen vinden. Al is de mogelijkheid dier splitsing, of laat ik liever zeggen het aanbrengen van verband tusschen die beide belastingen, geen privilegie van het hier anbevolen stelsel, het kan toch aan de meeste moeilijkheden, die zich hicr voordoen, op de eenvoudigste wijze tegemoet komen.

Dat die moeilijkheden niet gering zijn is den wetgever genoegzaam gebleken. De wetgever van 1873 (herziening gebouwd) heeft. er zijne aandacht niet aau gewijd en kon dit ook moeilijk anders hebben gedaan dan door de gebouwen "tot hoeven behoorende" van de herziening uit te sluiten en deze uit te stellen tot de herziening van de belastbare opbrengst der ongebouwde eigendommen, die echter nog zeer in de lucht hing. Daar nu die schatting dier boerderijen, bij gebrek an andere gegevens, geschiedde in verhouding tot de huurwaarde der boerderijen in 
de kommen der dorpeu, werd, zooals algemeen bekend is, eene te hooge belastbare huurwaarde aan die gebouwen toegekeud. Ook is genoegzaam bekend, dat die hooge huurwaarde, voor den dag tredende bij de herziening der ongebouwde eigendommen, dit werk heeft bemoeilijkt door het $5^{\circ}$ lid van art. 2 der wet van 25 April 1879, Stbl. $\mathrm{n}^{\circ}$. 89, luidende: "Bij de bepaling der hierbedoelde waarde (pacht- of huurwaarde) wordt rekening gehouden met de waarde, voor de grondbelasting aan de gebouwde eigendommen toegekend." De juiste oplossing zou zijn geweest toen de belastbare opbrengst dier gebouwde eigendommen op nieuw te regelen. De wetgever van 1897, die tot taak had nieuwe regelen vast te stellen voor eene schatting der gebouwde eigendommen, heeft roor de hoeven ook geen verband gezocht met de schatting aau de ongebouwde eigendommen toegekend, maar door de ervaring geleerd, getracht een anderen maatstaf voor die eigendommen te viuden dan de huurwaarde, n.l. $1 \frac{1}{2}$ pCt. der stichtingskosten van gebouwen, voldoende voor de uitoefening van het bedrijf in zijn bestaanden omvang naar de gebruiken der streek.

De uitkomsten bleken echter in de praktijk onbruikbaar, zoodat bij de wet van 11 Januari 1904, Stbl. $n^{\circ} 5$, die schatting werd vervallen verklaard en een nieuwe maatstaf werd aangelegd naar de huurwanrde van het woongedeelte of $3 \mathrm{pCt}$. stichtingskosten en de halve huurwarde der schuren of $1 \frac{1}{2}$ pCt. der stichtingskosten en werd bovendien het begrip "hoeven" prijs gegeven.

Wanueer men nu nagat, welke moeilijkheden de uitvoering dier wet van 1897 heeft ondervonden, dan zal daar tevens uit blijken, dat zich deze bij het aannemen der waarde als basis niet zoozeer zouden hebben doen gevoelen. Zij waren van tweeërlei aard.

Vooreerst was het moeilijk, de juiste grens te trekken of een gebouw viel onder de term "hoeve" of ook afzonderlijke huurwaarde had en wel voor de boerenwoningen in of in de nabijheid vall de kom van dorp of stad gelegen, en voor arbeiderswoningen, waarbij meer of minder land in gebruik was. Door hier verschillenden maatstaf aan te leggen moest men tot ongelijkheden komen en door voor allen huurwaarde als basis te nemen moest men noodwendig voor enkele categoriën tot te hooge uitkomsten komen, al bleef de evenredigheid beter bewaard. Slechts aanneming der warde tot grondslag kon hier betere uitkomsten geven.

De tweede moeilijkheid - en hierdoor is voornamelijk het 
verzet tegen de wet van 1897 ontstanu in de provincie Groningeu - betrof de oplossing der vraag of het gebouw te groot was "voor de uitoefening van het bedrijf in ziju bestanden omvang"; en in hoeverre die omstandigheid op de schatting van invloed moest zijn. Het is ontegenzeggelijk waar, dat indien eene boerderij uit 40 hectaren bestond en later is gesplitst in twee van twintig, het oorspronkelijke groote gebouw dan niet meer waarde heeft dan het nieuw gestichte op de boerderij van 20 hectaren, maar deze bewering gaat niet op voor de villa, welks bewoner voor tijdverdrijf een zestal koeien houdt, in vergelijking van den keuterboer met dat bedrijf. Hier kan wel is waar huurwaarde ook de oplossing brengen, maar de koopprijs doet dit in niet mindere mate.

\section{VII.}

Ook al is de'waarde alleen van de pacht afhankelijk, mag toch de eerste een beteren grondslag heeten, omdat de eerste meer constant is en een beteren maatstaf voor de gemiddelde pacht aangeeft, dan de wetgever het kan doen door het gemiddelde van eenige jaren voor te schrijven. Een enkel slecht jaar kan al vrij wat invloed hebben. Onvoorziene en onverklaarbare omstandigheden kuunen een enkel maal onverwachte uitkomsten geven.

De vroeger door mij genoemde grondeu onder Oldebroek van slechter kwaliteit, die naar de gemiddelde opbrengst van de jaren 1877-1881 (basis krachtens de wet van 1879) op f 20.per hectare zijn geschat, hebben het vorig jaar in pacht opgebracht voor de eerste snede hooi f 50 per hectare, de naweide niets. Zelfs voor het overvloedige gewas, dat er toen op stond, was dit volgeus algemeen oordeel der omwonenden veel te duur.

Ook de zooveel lagere opbrengst van het grasgewas op het vroeger door mij genoemde perceel in Epe, in $1903 \mathrm{f} 140 .-$ en de drie vorige jaren $\mathrm{f} 203$.- en $\mathrm{f} 228 .-\mathrm{i}$ is een geheel toevallige.

De fransche wet van 3 Frimaire, An VII, bij de invoering van! het kadaster van kracht, heeft dit bezwaar willeu ondervangen door in art. 56 voor te schrijven, dat voor bouwlanden de opbrengst gemiddeld per jaar berekend moet worden "en formant l'aunée commune sur quinze années antérieures, moins les deux plus fortes et les deux plus faibles. Les aunées de la 
circulation du papier-monnaie à partir du 1 Janvier 1791 (vieux-style) ne compteront point."

De artikelen 58,60 en 62 behelsden gelijke bepalingen omtrent l'année commune voor moestuinen, wijnbergen en graslanden. Bij de invoering van het kadaster hier te lande werd de gemiddelde pachtprijs over 1816-1826 tot groudslag genomen, terwijl het tarief van den prijs der producten werd opgemaakt over de jaren 1812-1826 (Kon. besluit vau 22 Juni 1826, $\mathrm{n}^{\circ}$ 108). Waarschijnlijk is de wetgever van 1879 voor den omvang en de aau onmogelijkheid grenzeude moeilijkheid tot het verkrijgen der noodige gegevens gezwicht om op gelijke wijze aan die bezwareu van exceptioneele jaren of prijzen tegemoet te komen en heeft zij l'année commune voor pachtprijzen op 5, voor koopprijzen op 7 gesteld. Aanneming der waarde tot basis had al die bezwaren op envoudige wijze voorkomen.

VIII.

De schatting der waarde van de eigendommen zou behalve eeu beteren maatstaf voor de grondbelasting, tevens een.goede basis kunnen opleveren voor de invoering eener belasting op de coujunctuurwinst.

Over deze winst komt eene beschouwing voor in de Vragen des Tijls 1902 II, bl. 57 vlg. van de hand van den heer K. Reijne.

Uitvoeriger en stelselmatig wordt dit onderwerp behandeld in de Jahrbücher für Nationalökonomie und Statistik, Band 25, März 1903, door Dr. F. Pabst, Die Besteuerung des unverdieuteu Wertzuwachses von Grund und Boden (Konjuncturgewinnsteuer), die het in 5 afdeelingen heeft gesplitst n. l. I. Ueberblick über die heutige Besteuerung des Konjuncturgewinnes in PreuszeII. II. Finanzwissenschaftliche Begründung der Konjuncturgewinnsteuer. III. Kritische Prüfung von Vorschlngen. IV. Versuch einer brauchbaren Steuerform. V. Verwendung der Erträge der Konjuncturgewinnsteuer. Voor beschouwing in miju bestek komen slechts de afdeelingen III en IV in aanmerking.

Adickes wil de grondbelasting heffen voor de gebouwen en de gronden, bij den landbouw in gebruik, naar de opbrengst, voor de bonwterreinen nar de jarrlijks vast te stellen waarde, terwijl de conjunctuurwinst belast zou worden door eene progressieve 
heffing van bouwterreinen en gebouwen. Om bovendien plotselinge winsten te belasteu, wil hij opcenten op de overgangsrechten heffen, en wel voor die gronden, die iu een bepasld tijdsverloop niet zijn overgegaan.

Bovendien stelt Adickes eene progressieve heffing voor van het verschil tusschen den gerealiseerden koopprijs en de voor de grondbelasting vastgestelde waarde.

Ook Fberstadt wil de overgangsrechten gebruiken ter bereiking van het doel, doch slechts voor de hoogere waarcle bij de verwisseling van productieven grond in bouwterrein en wel door progressieve heffing van $\frac{1}{2}-4$ pCt. van de waarde van deu grond boven 2500 Mrk.

Aan beide voorstellen kleeft echter het groote bezwaar, dat de belasting geheven wordt in de onderstelling van conjunctuurwinst, dus ook al is deze eigenlijk niet behaald. Bovendien wordt bij Adickes die winst voortdureud belast, terwijl zij toch uit economisch oogpunt slechts eenmaal belast mag worden (bl. 359).

Vandaar dat Neumann voorstelt slechts de werkelijk gemankte winst te belasten, zoonls deze door behoorlijke schatting om de 15 jaar is vastgesteld, waarbij verbeteriugen en aangewende kapitalen in rekening dienen gebracht, door de boeken van den eigenaar uit te wijzen.

Pabst echter is bevreesd, dat die schattingen tot ongelijkmatigheden aanleiding zullen geven, vooreerst wegens den laugen termijn waardoor groote veranderingen in de warde kunneu hebben plaats gegrepen en vervolgens omdat eene behoorlijke waardebepaling voor de bouwterreinen uiterst moeielijk is, waar eene opbrenget als criterium ontbreekt.

$\mathrm{Hij}$ gaat van het juiste standpunt uit dat de zuivere conjunctuurwinst uit het prijsverschil tusschen koop en verkoop moet worden afgescheiden, door bij den koopprijs alle moeite en kosten, die den eigenaar gemaakt heeft om die winst te behaleu, het in orde maken van het terrein, renteverlies enz. op te tellen. Warrom hij echter het renteverlies slechts over een bepaald aantal jaren wil berekenen, is mij niet recht duidelijk. Het gevaar, dat bouwterrein achtergehouden zou worden, wanneer dit renteverlies volledig in rekeuing zou komen, is denkbeeldig; wanneer de rente niet eens is goedgemaakt, is er geen conjunctuurwinst. Bovendien wordt door Pabst zelf erkend, dat een 
algemeen geldende regeling voor de beperking van den tijd, wanrover die rente berekend moet worden, niet te geven is.

Om verder ook daar het "unearned increment" te belasten, wanr het zich niet in des gemaakten verkoopprijs openbaart, omdat grondeigeuaar, bouwterrein-speculant, bouwondernemer en huiseigenaar iu één persoon vereenigd zijn, wenscht hij het stelsel van Neumaun toe te passen, n.l. periodieke schattingen, doch om de bezwaren, tegen dat stelsel ontwikkeld, te ontkomen, zouden die schattingen om de 5 jaar moeten plaats hebben en zich moeten bepalen tot buizen, daar hier uit de huren de waarde kan bepaald worden. Voor de bouwterreineu zou, indien geen verkoop had plaats gehad, waardoor de winst bepaald zou kunnen worden, gewacht moeten worden tot de bebouwing, wanrna de koopprijs berekend zou kunnen worden uit den huurprijs, na aftrek der stichtingskosten van het huis.

Het komt mij voor, dat hier de bezwaren, tegen het stelsel van Neumann, nl. "de mislukte Bremer pogingen in 1873 " te zwaar hebben gewogen en de door mij voorgestane schattingen der verkoopwaarde een zeer goeden maatstaf zouden geven voor de te berekenen conjuctuurwinst op dezelfde wijze als hier voor de bebouwde gronden is voorgesteld. Bovendien wordt daardoor tevens het bezwaar ondervangen, door Pabst zelf opgeworpen, tegen de berekening der verkoopwaarde uit de huurprijzen, nl. dat deze voor de kleine woningen te hoog in verhouding tot de groote en elegante woningen berekend zou worden, welke misstand er in vele gemeenten al toe geleid heeft de grondbelasting naar de warde te heffen.

Wel stelt hij die ondervanging op andere wijze voor, n.l. door de huren naarmate de grootte der woningen van 3-6 pCt. te verminderen, maar hier wordt het gebied der wettelijke ficties betreden, dat vooral bij deze belasting, die uit den aard zwarr moet zijn, noodig moet worden vermeden.

Ook stelt hij voor slechts in deze belasting te betrekken :

$I$ in cultuur zijude gronden, doch reeds geschikt voor bouwterreinen,

II bouwterreinen, en

III bebouwde grondoppervlakten.

Toch is er in nog vele andere gevallen unearned increment, men denke slechts aan de hoogere waarde, die een 
geheele streek verkrijgt door den annleg van een spoorweg, terwijl ook bij de groote steden de vrang, hoever zich de onder I genoemde gronden uitstrekken, tot moeilijkheden en onbillijkhedeu zou aanleiding geven. In waar hij betrekkelijk de belasting der eerste categorie bijzondere zwarigheden voorziet, geven de door mij voorgestane schattingen alle gewenschte uitkomsten.

Hier zij het mij vergund, naar aanleiding van bovenstaande schets dezer belasting, twee opmerkingen te maken en wel eerstens, dat in het tweede onderdeel door Pabst betoogd wordt dat voor terugbetaling bij ongunstige conjuctuur, tengevolge het principe der belasting naar dragkracht, geen termen bestaan. Dit nu is juist, wanneer de conjunctuurwinst berekend is bij eigendomsovergang, doch het gaat niet op bij berekening tengevolge van periodieke schatting. Al moge aan de teruggave groote bezwaren zijn verbonden, ernstige politici, zooals Pabst beweert, de gemeenten (het Rijk) niet aan de gevaren willen blootstellen aan de overneming van dergelijke kansen verbonden, de billijkheid brengt mede, dat als men die belasting aanvardt, deze ontheffing even goed moet plats hebben als in alle audere belastingwetten, waar teruggave wordt bevolen, indien de heffing blijkt onjuist te zijn geweest. Men heeft hier niet met eene zakelijke belasting te doen, men belast alleen de winst, zoo die gemaakt is en bij hem, die hanr gemaakt heeft. Een voorbeeld kan dit gemakkelijk toelichten. Wij nemen hier de door mij voorgestelde schattingen om de 10 jaren.

A. had twee perceelen bouwterrein, in 1900 elk geschat op f 5000.-, in 1910 zijn deze stukken $\mathrm{f} 6000$. - ward, maar hij verkoopt perceel I aan B. A. betaalt nu belasting naar f 1000. - voor de beide stukken. $\mathrm{Nu}$ treedt ongunstige conjunctuur in, waardoor in 1920 die stukken f 5000.- waard zijn. Voor het perceel II heeft A. dus geen wiust gemarkt en behoort dus de in 1910 geheven belasting te worden gerestitueerd. B. heeft geen belasting van de winst van perceel I betaald en behoeft dus niets terug te ontvangen, terwijl A., die in 1910 van dat stuk f 1000 . - winst heeft gemaakt, terecht daarvoor betaald heeft.

Het tweede punt betreft het denkbeeld van Pabst om de belasting naar het principe der draagkracht progessief te makeu. Ook dit komt mij voor in strijd te ziju met de bedoeling dezer 
belasting, hierboven aangeduid. Waar hij zelf voorop stelt, dat bezit van kleiner of grooter vermogen der belastingschuldigen niet in aanmerking mag komen voor de grootte der belasting bij gelijke winst, kan ik geen redelijken grond ontdekken, waarom 25 pCt. belasting betaald moet worden, wanueer de waarde van een bouwterrein van f 2000 . - tot $f 4000$.- is gestegen en slechts $10 \mathrm{pCt}$. wanneer van een ander perceel die waarde is gestegen van $f 20.000$ tot $f 22.000$. De eigenaar heeft toch in beide gevallen $f 2000$. - conjunctuurwinst gemaakt.

IX.

Resumeerende kom ik dus tot de volgende voordeelen, in de punten III-VIII door mij ontwikkeld:

$1^{\circ}$. Omstandigheden, die eene hoogere waarde ann een perceel geven, zonder zich in den huurprijs af te spiegelen, worden in de belasting betrokken.

$2^{\circ}$. Belasting naar het productief vermogen komt beter tot haar recht.

$3^{\circ}$. Het verschil tusschen gebruiks- en handelswaarde wordt in de belasting betrokken.

$4^{\circ}$. Meu kan tot eene juiste splitsing komen tusschen de belasting gebouwd en ongebouwd, zoowel in de steden als bij de boerderijen.

$5^{\circ}$. Koopprijs is een betere maatstaf, omdat hij niet aan de schommelingen van huurprijzen onderhevig is.

$6^{\circ}$. Eventueele invoering eener belasting op de conjunctuurwinst is mogelijk.

Hieraan zou ik als zevende voordeel nog kunnen toevoegen een juister aanslag der eigeudommen in de vermogensbelasting. Eendeels omdat dit voordeel een bijkomstige is, anderdeels omdat de wenschelijkheid vanzelf spreekt, dat niet het eigendom van den een soms voor de helft, van den ander volledig in aanmerking komt bij de berekening voor die belasting, zooals thans dikwijls het geval is, heb ik er geene afzonderlijke afdeeling an gewijd. Ook overigens hoop ik voldoende te hebben angetoond, dat de vraag, ann het slot van punt II van dit opstel gesteld, of de voordeelen van het aannemen van den koopprijs tot basis van schatting, in plants van de huurwaarcle, de nadeelen overtreffen, toestemmend moet worden beantwoord.
Apeldoorn, April 1904.
H. P. Cramer.

Ecor. 1904. 